\title{
What is the urban in the contemporary world?
}

\author{
O que é o urbano, no mundo contemporâneo?
}

\author{
1 Centro de Desenvolvimento \\ e Planejamento Regional, \\ Universidade Federal \\ de Minas Gerais, \\ Belo Horizonte, Brasil. \\ Correspondence \\ R. L. Monte-Mór \\ Centro de Desenvolvimento \\ e Planejamento Regional, \\ Faculdade de Ciências \\ Econômicas, Universidade \\ Federal de Minas Gerais. \\ Rua Curitiba 832, \\ Belo Horizonte, $M G$ \\ 30170-120, Brasil. \\ montemor@cedeplar.ufmg.br
}

\section{Abstract}

Central concepts of contemporary life such as politics, civilization, and citizenship derive from the city's form and social organization. The city expresses the socio-spatial division of labor, and Henri Lefèbvre proposes to view its transformation within a continuum from the political city to the urban, whereby it completes its domination over the countryside. The city's transformation into the urban takes place when industry brings production (and the proletariat) into that space of power. The city, locus of surplus, power, and the fiesta, a privileged scenario for social reproduction, was subordinated to the industrial logic and underwent a dual process: its centrality imploded, and its outskirts exploded on surrounding areas through the urban fabric, bearing with it the seeds of the polis and civitas. The urban praxis, formerly restricted to the city, re-politicized social space as a whole. In Brazil, the urban has its origins in the military governments' centralizing and integrating policies, following Vargas's expansionism and Kubitschek's developmental interiorization (or occupation of the hinterlands). Today, urban-industrial processes impose themselves over virtually all social space, in contemporary extended urbanization.

Cities; Urbanization; Urban Health
Roberto Luís Monte-Mór 1

\section{Introduction}

The relationship between the city and the countryside is situated historically and theoretically at the center of human societies. The city's domain over the countryside, as the result of the division between intellectual and manual labor and through the market's command over productive activities, has marked human societies since ancient times, and particularly in the modern capitalist industrial societies to which we belong. However, the adjectives urban and rural, referring to the city and the countryside, only recently gained autonomy in the sense of referring to a range of cultural, socioeconomic, and spatial relations between forms and processes deriving from them respectively, however without allowing the dichotomous clarity that characterized them until the last century. On the contrary, the borders between urban and rural space are increasingly diffuse and difficult to identify. This may occur because these adjectives currently lack their original substantive reference, to the extent that city and countryside are both no longer pure concepts that are easy to identify or demarcate. What are the cities of Belo Horizonte, São Paulo, Rio de Janeiro, Bela Vista de Minas, or any other large, medium-sized, or even small cities in contemporary Brazil or in the world? Where do they begin, and where do they end? On the other hand, what is the countryside today? Does it consist 
of remote villages or the outskirts of cities, the so-called "rural area"? Is it large ranches, agribusinesses, or settlements of the Landless movement, in the Northeast, the cerrado (savannah), or the Amazon? At any rate, the definition of the limits and nature of both the city and rural versus urban areas is increasingly diffuse and difficult.

Cities in Brazil are defined legally by the city limits of municipal centers and districts (or townships), and thus what are considered urbanized territories and populations include the city limits of towns serving as the seats of municipal districts or townships. However, urbanized areas encompass broad areas neighboring on cities whose integrated urban space extends over adjacent and distant territories, in an expansion process that began in the 19th century and was accelerated irreversibly in the 20th century.

In addition, the cities, or the political and socio-cultural space formed on the basis of them, became the center of organization for society and the economy. On the international scale, a handful of cities organize and command major interest blocs and reorder the global economic space 1,2. On the local, regional, and national scales the cities define forms of organization and location of economic activities and the population, provide the references for social identities, and define modes of community constitution. Indeed, central concepts in contemporary life derive from the city's spatial form and social organization. The Greek notion of polis comes from the concept of politics; the Latin civis and civitas give us citizen, citizenship, city, and civilization, implying the existence of cities. Peoples which did not produce cities, such as the semi-nomads of Americas, were considered uncivilized, as opposed to the Mayan, Aztec, and Inca "civilizations", even though ethno-historical, anthropological, and archeological approaches now question such classifications and the very concept of city ${ }^{3}$.

Latin also gives us the term urban, with a double connotation: urbanum (plow) came from the sense of settlement, the physical form of the space demarcated by the furrow of the plow pulled by the sacred oxen, marking the territory for Roman production and life; thence came the terms urbe and urbs, the latter referring to Rome, the Imperial city and center of the world, which disappeared until the resurgence of large cities in the modern era. The term urban was retrieved in the $16^{\text {th }}$ century 4 to refer to the Imperial city, especially the city that was headquarters to the British Empire under construction 5 , where the word city 6,7 relates to the financial center London as opposed to the countryside in the Victorian Age.

City and countryside, opposite and complementary socio-spatial elements, thus constitute the centrality and periphery of power in socio-spatial organization. Cities guarantee diversity and scale for competition and cooperation in human life. The countryside, which is also diverse, guarantees the homogeneities and production for competition and cooperation, managed by the cities and limited within its growing dependency.

The city, according to the prevailing view of political economics, results from the deepening socio-spatial division of labor and the opening to other communities and regular processes of exchange. It also implies sedentary life, socio-spatial hierarchy, and a power structure sustained by the extraction of a regular surplus from collective production, in addition to regular flows of goods and persons between communities. The city thus presupposes the emergence of a dominant class that extracts and controls this collective surplus through ideological processes accompanied by the use of force.

According to Paul Singer 8, the city is the mode of socio-spatial organization that allows the ruling class to maximize the regular extraction of surplus production from the countryside and transform it into a food base for its own sustenance and that of the army that guarantees its regular extraction. This therefore establishes what Henri Lefèbvre 9,10 referred to as the "political city", that is, the city that maintains it domain over the countryside (with the resulting extraction of surplus production) based on political control. In this context, the countryside is the space for production and the city is the space for control of the surplus, the locus of political and ideological power which extracts from the countryside the conditions for reproduction of the ruling class and its direct military and civil servants. According to the heterodox hypothesis presented by Jane Jacobs 11 and rejected for decades, the city has always been more productive than the countryside, which in fact guaranteed its domain, while it often produced the rural space $a$ posteriori. This precedence of the city over the countryside has been reclaimed in the legendary city of Jericho, among others 12.

However, Lefèbvre proposes that one consider a continuum of the political city with the 
"critical zone" (the urban), including the merchant city and the industrial city. The first passage is marked by the entry of the marketplace inside the walls of the cities controlled by the monasteries or castles. Encouraged by the fair (which can be regional and even "internation$a l$ "), the elites gradually allowed the entry of the bourgeoisie into the sphere of power, soon shifting the centrality of the palaces and monasteries to the market square, consolidating this economy which has its privileged space in the cities.

Thus, the merchant city, the central place where regional surpluses were voluntarily brought and marketed, resulted from the entry of the bourgeoisie into the city (and eventually taking it over). The merchant burghers gave the political city a new meaning and force, transforming it into a mercantile center. The countryside-city relationship thus underwent its first major shift, and the extraction of surplus production was no longer made possible only by political/ideological and military coercion, but also resulted from a voluntary shift from the countryside towards the articulating capacity of the city as the market locus. The shift from the countryside to the city was thus marked by the economy: the countryside's production was only realized on the market square, thus modifying and expanding the city's domination over the countryside. Note also the synergy of urban life in the merchant city, the central place for innovation and provision of goods and services for production in the countryside and also the privileged space for life in community where the division of labor was deepened through the specialties and complementary relations that developed there.

\section{The industrial city, the city-countryside relationship, and the emergence of the urban}

The second transformation and actual shift from city to urban was marked by the entry of industry into the city, a long process in Western history, as emphasized by Singer 8 . In fact, urbanization as we understand it today began with the industrial city. Until the emergence of factory industry and its concentration in European cities, the urbanization process was limited to a handful of cities where power and/or the market were concentrated. There were few human agglomerations that could now be called cities during the period preceding the "industrial revolution". The proportion of the total population living in cities was no more than $20 \%$ in nearly all of the countries 13 , and the city was a fundamental condition for the development of industry, concentrating in just a few cities, as in Brazil until recently, the consumer population, workers, and "general conditions of production" for the installation of factory companies. These general conditions of production 14,15 , whether existing or to be created, include: the state's provision of the legal apparatus which guarantees relations of private ownership and free circulation of merchandise (including land and the work force), transportation and communications services, and provision of the basic infrastructure and services for industrial and financial capital, as well as for the reproduction of the work force.

The industrial city was thus marked by the entry of production into the center of power, bringing with it the working class, the proletariat. The city began to not only control and market the production of the countryside, but also to transform and add value to it in unprecedented ways and amounts. The countryside, until then predominantly isolated and self-sufficient, began to depend on the city for its own production, from tools and implements to various types of consumer goods, thus depending on urban-industrial production even for basic foodstuffs and consumer goods. According to Lefèbvre 10 , this shift meant the total subordination of the countryside to the city.

In industrial city there was also a radical transformation. Industry imposed its production-centered logic on the city. Meanwhile the city's space, previously organized as the privileged locus for the economic surplus, political power, and cultural fiesta, legitimized and ruled as a work value and (collective) use value, became increasingly privatized and subordinated to exchange value. According to Lefèbvre, the city itself also became an industrial product, according to the same economic laws ruling production. The privileged space for reproduction of society was thus subordinated to the logic and needs of industry, combining the necessary conditions of production, amongst which the collective reproduction of the work force, synthesized in housing. Castells 16 defined the specificity of urban space within the capitalist economic system as the privileged locus for the reproduction of the work force, made possible by the concentration of the "means of collective consumption".

The urbanized space, in this context, thus began to constitute itself as a function of the demands placed on the state both to serve industrial production and especially the needs of collective reproduction of the work force. The 
large industrial cities which then extended over their peripheries aimed mainly to accommodate factories and their suppliers and workers, generating wide urbanized areas around them, namely the metropolitan areas.

However, the city, as the locus for the triad of collective surplus, political power, and cultural fiesta did not disappear, since it synthesized the society that generated it. Lefèbvre 10 describes metaphorically what happened to it: the industrial city underwent a dual process of implosion and explosion. Implosion took place in the centrality of surplus/power/fiesta, concentrating and reactivating the symbols of the citadel threatened by industrial logic. In the current industrialization process, this partially explains the emphasis on the "revitalization of central areas", symbolic spaces of political power and the reclaiming of the elites' use value, more or less accessible to the population as a whole.

Explosion occurred on the surrounding space by extending the urban fabric in this socio-spatial form/process bearing with it the conditions of production previously restricted to the cities, over the immediate countryside, eventually reaching the distant regional space according to the demands of production (and collective reproduction). The urban fabric thus synthesizes the process of expansion of the city's $u r$ ban phenomenon over the countryside and virtually over the regional and national space as a whole.

\section{Contemporary urbanization: its extensive nature and other implications}

In short, what is urban in the contemporary world, this "fabric" that is born in the cities and extends beyond them, over the countryside and regions? Urban, from this perspective, is a synthesis of the old city-countryside dichotomy, a third element in the city-countryside dialectic opposition, the material and socio-spatial manifestation of contemporary urban-industrial society extended virtually throughout the social space. Lefèbvre 10 uses the expression urban society as the dialectic (and virtual) synthesis of the city-countryside dichotomy, overcome in the contemporary stage of capitalism which he terms "the bureaucratic society of controlled consumption" 17 . The urban, or contemporary urban-industrial space, a metaphor for the social space (re)defined by urbanization, extends virtually throughout territory through the urban fabric, this socio-spatial form which both inherits and bequeaths the city that char- acterizes the contemporary urban phenomenon and urban society.

"The urban fabric proliferates, spreads, and corrodes the remains of agrarian life. These words, 'the urban fabric', do not strictly designate the built-up domain of cities, but the set of manifestations of the city's predominance over the countryside. From this view, a second home, a highway, a supermarket in the middle of the countryside, are all part of the urban fabric" 10 (p. 17).

However, the industrial city, which overflowed onto surrounding areas, gave rise to a new form of urbanization which simultaneously extended and integrated the city's own sociopolitical and spatial praxis and urban-industrial space (which Lefèbvre called urban praxis) to social space as a whole. To the extent that the urban fabric extended through territory, it took with it the seeds of the polis, of the civitas, of the urban praxis that was proper and limited to the city's space. The political struggle for control of the collective means of reproduction that characterized the 1970s and the urban social movements that emerged during that period showed that citizenship was latent to cities and urban areas. However, the 1980s showed that these movements had extended beyond such limits, reaching the entire social space. Social movements lost the adjective "urban" to the extent that they came to encompass rural and traditional populations, such as indigenous peoples, rubber tappers, and landless workers, among others.

Thus, the urban issue had become the spatial issue itself, and urbanization came to constitute a metaphor for the production of contemporary social space as a whole, potentially covering the entire national territory in urbanindustrial bases. On the other hand, the politicization proper to the urban space, now extended to regional space, reinforces concerns over the quality of daily life, the environment, and the expanded reproduction of life. The industrial became subjected (at least virtually) to the limits of the urban and the demands of reproduction. In this context, the re-politicization of urban life becomes the re-politicization of social space: “...the issue of space, which subsumes the problems of the urban sphere (the city and its extensions) and daily life (controlled consumption) replaced the issue of industrialization" 18 (p. 89).

I have used the term "extensive urbanization" $19,20,21$ as this socio-temporal materialization of the processes of production and reproduction resulting from the confrontation between the industrial and the urban, plus the so- 
cio-political and cultural issues intrinsic to the polis and the civitas that have extended beyond urban agglomerations to social space as a whole. This term, for which I assume full responsibility (although it takes inspiration from Lefèbvre), is intended to reclaim central aspects of the urban phenomenon, combining the socio-spatial dimension and the political element implicit to urban praxis. It is this social spatiality resulting from the explosive encounter between industry and city - the urban - which extends with relations of production (and its reproduction) throughout the entire space where the general conditions of production (and consumption) determined by state industrial capitalism are imposed on the bureaucratic society of controlled consumption which bears the political reaction and organization proper to the city. This reality - urban society - virtually imposes itself in Brazil today, constituting a condition for understanding contemporary social space.

\section{The extensive urbanization of contemporary Brazil}

Given the above, one can already speak of a virtually urban society in Brazil. Brazilian urbanization intensified in the latter half of the 20th century, when industrial capitalism gained force in the country and dynamized the economy based on the consolidation of the large industrial cities, particularly São Paulo, the national hub. The transformation of an agro-export economy into an economy centered on import substitution for the domestic market redefined the industrial city as a pole for dynamization and selective transformations in Brazilian territory and society.

The industrial city emerged in Brazil from two main watersheds, not necessarily mutually exclusive: the first, the transformation of the political city, traditional headquarters for the state bureaucracy and space for the command of the rural oligarchies linked to the agro-export economy, into a mercantile city, marked by the presence of export capital and/or the concentration of commerce and central support services for rural productive activities in a center for industrial production; the second, the creation and/or capture of small cities as spaces for mono-industrial production by large industries. Only these industrial cities, whether large or small (mono-industrial), combined the conditions required by industrial capitalism, where the state regulated the relations between capital and labor, made infrastructure investments, guaranteed the means for collective con- sumption, in a word, created the general conditions of production for industry. These conditions of production were limited to what Milton Santos 22 called the "urban archipelago", highlighting the fragmented and disarticulated nature of Brazilian urban society. In this context, the industrial city was the central component in the capitalist dynamic, linking to outside commercial cities and urban centers which channeled production to their area of influence and control. Only these cities additionally concentrated the possibilities for access to the facilities of modern life, citizenship, and urbanity.

The urban fabric, in Brazil, had its origin in the territorial policy (both concentrating and integrative) practiced by the military governments following the centralization and expansionism of the Vargas period and the interiorization (i.e., inland shift) of development during the Kubitschek Administration. The dyad "Energy and Transportation" was expanded to investments in infrastructure, communications, and industrial and financial services, among others. International capital coming to Brazil joined the construction industry, the subsidized large landholdings, and agribusiness as part of the agreements among the domestic and regional economic elites to support (inter) national militarism. The state apparatus, labor and social security legislation, communications networks, urban and social services (for production and consumption) extended through the urban fabric virtually throughout the country, from the dynamic centers to the frontiers of natural resources.

Beginning in the 1970s, urbanization extended virtually throughout the Brazilian territory, integrating the various regional spaces into the urban-industrial centrality emanating from São Paulo, developing into the network of regional metropolises, medium-sized cities, and urban centers affected by large-scale industrial projects and finally reaching the small cities in the various regions, particularly where the modernization process gained a more intense and extensive dynamic. "There is no longer an agrarian issue; the issue is now urban on a national scale", proclaimed economist/ sociologist Francisco de Oliveira at the meeting of the Sociedade Brasileira para o Progresso da Ciência (Brazilian Society for the Advancement of Science) in 1978, in a paper that came to be known as the "roadmap for Brazilian urbanization" 23. In fact, by the end of the 1970s capitalist relations had extended virtually throughout Brazilian territory.

This urbanization that occurred beyond the cities and urbanized areas, bearing with it the 
urban-industrial conditions for production (and reproduction), as well as the urban praxis and the sense of modernity and citizenship, are what I refer to as extensive urbanization. In the last thirty years, extensive urbanization has reached practically the entire country, extending from the metropolitan regions and linking to the industrial centers, the sources of raw materials, following the transportation, energy, and communications infrastructure, creating and extending the conditions of production and the means for collective consumption necessary for consumption of Fordist industrial production that was implanted in the country beginning with the "Brazilian miracle". In the late 20th century, urban made its presence felt throughout the national territory, particularly on the Amazon and Central-West frontiers, where the production of space already occurred through an urban-industrial base emanating from the metropolitan centers and their spinoffs in the agrarian areas linked to the country's agro-industrial base.
In this broader sense, one can speak of an extensive urbanization imposing itself on Brazilian space far beyond the cities, integrating rural and regional spaces with urban-industrial space through the expansion of the material base required by the contemporary society and economy and the relations of production which are (or should be) reproduced by the production of space itself. Within this context there is a multiplication of (urban) frontiers, both internally and on the fringes of agglomerations as well as in regional and rural spaces incorporated into the prevailing urban-industrial logic. Extensive urbanization thus moves along various transportation corridors and communications and services networks in "new" regions like the Amazon and the Central-West, but also in "old" regions like the Northeast, in residual spaces of more developed regions, and in the "islands of rural life" in the hinterlands of Minas Gerais or São Paulo. All over Brazil, the urban-industrial logic imposes itself on contemporary social space, defining what is urban in our present-day life.

\section{Resumo}

Conceitos centrais da vida contemporânea - política, civilização, cidadania - derivam da forma e organização da cidade. A cidade expressa a divisão sócio-espacial do trabalho, e Henri Lefèbvre propõe pensá-la do ponto de vista de um continuum da cidade política ao urbano, no qual se completa a dominação do campo. A passagem da cidade ao urbano foi marcada por a indústria trazendo a produção - e o proletariado para o espaço do poder. A cidade, locus do excedente, do poder e da festa, cenário privilegiado da reprodução social, ficou, assim, subordinada à lógica industrial e sofreu, então, duplo processo: sua centralidade implodiu sobre si mesma e sua periferia explodiu sobre o entorno através do tecido urbano, que carregou consigo o germe da pólis, da civitas. A práxis urbana, antes restrita à cidade, repolitizou todo o espaço social. No Brasil, o urbano teve origem na política concentradora e integradora dos governos militares, em seqüencia ao expansionismo varguista e à interiorização desenvolvimentista juscelinista. Hoje, o urbano-industrial se impõe virtualmente a todo o espaço social, na urbanização extensiva dos nossos dias.

Cidades; Urbanização; Saúde Urbana 


\section{References}

1. Friedmann J. Life space and economic space: essays in Third World planning. Oxford: Transaction Books; 1988.

2. Sassen S. The global city. New York/London/ Tokyo/Princeton: Princeton University Press; 1991.

3. Monte-Mór RL. Modernities in the jungle: extended urbanization in the Brazilian Amazonia [Ph.D. Thesis]. Los Angeles: University of California, Los Angeles; 2004.

4. Houaiss A, Villar M, Franco FMM, Instituto Antônio Houaiss de Lexicografia. Dicionário Houaiss da língua portuguesa. Rio de Janeiro: Objetiva; 2001.

5. Lexicon Publications. The new Lexicon Webster's dictionary of the English language. Encyclopedic Edition. New York: Lexicon Publications; 1987.

6. Williams R. The country and the city. New York: Oxford University Press; 1973.

7. Williams R. Keywords: a vocabulary of culture and society. London: Fontana Paperbacks; 1983.

8. Singer PI. Economia política da urbanização; ensaios. São Paulo: Editora Brasiliense; 1973.

9. Lefèbvre H. O direito à cidade. São Paulo: Editora Documentos; 1969.

10. Lefèbvre H. A revolução urbana. Belo Horizonte: Editora da UFMG; 1999.

11. Jacobs J. The economy of cities. New York: Random House; 1969.

12. Soja EW. Post-Metropolis: critical studies of cities and regions. Oxford: Blackwell Publishers; 2000.

13. Davis K. Cidades: a urbanização da humanidade. Rio de Janeiro: Zahar; 1970.

14. Topalov C. La urbanización capitalista: algunos elementos para su análisis. México DF: Editorial Edicol México; 1979.

15. Lojkine J. O estado capitalista e a questão urbana. São Paulo: Martins Fontes; 1981.
16. Castells M. A questão urbana. Rio de Janeiro: Paz e Terra; 1983.

17. Lefèbvre H. A vida cotidiana no mundo moderno. São Paulo: Editora Ática; 1991.

18. Lefèbvre H. The production of space. Oxford/ Cambridge: Blackwell; 1991.

19. Monte-Mór RL. Urbanização extensiva e novas lógicas de povoamento: um olhar ambiental. In: Santos M, Sousa MA, Silveira ML, organizadores. Território: globalização e fragmentação. São Paulo: Editora Hucitec/Associação Nacional de Pós-graduação e Pesquisa em Planejamento Urbano e Regional; 1994. p. 169-81.

20. Monte-Mór RL. Urban and regional planning: impact on health and the environment. In: Shahi GS, Levy BS, Binger A, Kjellström T, Lawrence R, editors. International perspectives on environment, development, and health: toward a sustainable world. New York: Springer Publishing Co.; 1997. p. 554-66.

21. Monte-Mór RL. Outras fronteiras: novas espacialidades na urbanização brasileira. In: Castriota LB, editor. Urbanização brasileira: redescobertas. Belo Horizonte: Editora C/Arte; 2003. p. 260-71.

22. Santos M. Técnica, espaço, tempo: globalização e meio técnico-científico informacional. São Paulo: Editora Hucitec; 1994.

23. Oliveira F. Acumulação monopolista, contradições urbanas, e a nova qualidade do conflito de classes. In: Moisés JA, organizador. Contradições urbanas e movimentos sociais. Rio de Janeiro: Paz e Terra; 1978. p. 65-76.

Submitted on 22/Dec/2004

Final version resubmitted on 10/Feb/2005

Approved on 14/Feb/2005 